Research Article

\title{
Design and Validation of Inquiry-based STEM Learning Strategy as a Powerful Alternative Solution to Facilitate Gifted Students Facing 21st Century Challenging
}

\author{
Abdurrahman ${ }^{1}$, Farida ARIYANI ${ }^{2}$, Hervin MAULINA ${ }^{3}$, and Novinta \\ NURULSARI ${ }^{4}$
}

Received: 20 January 2019 Accepted: 11 March 2019

\begin{abstract}
Engagement in STEM across the primary-secondary school transition has been widely investigated. However, integrated-STEM implementation had not shown practical packaging and could not reach all the skills that gifted students needed in the 21st century. The main perspective of STEM education refers to the conclusion that the learning approach was student-centered. The concept of this point of view was like an inquiry-based approach, where the inquiry approach was oriented to fostering student inquiry skills through active experiments. The purpose of this study was to design and validated an inquiry-based STEM learning strategy design that could systematically guide instructors or designers in creating an appropriate gifted students learning activities oriented to 21 st century skills. Using an established method for model development research, a theoretically constructed initial model was iteratively improved and underwent internal validation through expert review. In a field study of an inquiry-based STEM learning strategy, we examine the design and operational characteristics that were important for the expressive role of the learning strategy. The pilot study indicated that the inquiry-based STEM learning strategy could improve gifted students' abilities in accordance with 21 st century learning frameworks.
\end{abstract}

\section{Keywords}

giftedness, STEM inquiry-based learning, 21st century skills

\section{To cite this article:}

Abdurrahman, Ariyani, F., Maulina, H., \& Nurulsari, N. (2019). Design and validation of Inquiry-Based STEM learning strategy as a powerful alternative solution to facilitate gifted students facing $21^{\text {st }}$ century challenging. Journal for the Education of Gifted Young Scientists, 7(1), 33-56. DOI: http://dx.doi.org/10.17478/jegys.513308 


\section{Introduction}

Everyone's cognitive skills are different, as well as when they show differences in their emotions and thoughts. In response to pedagogical challenges in 21st century education, gifted students were required to master higher order thinking skills. Even gifted students expressed that critical thinking skill was needed (Schreglmann, \& Öztürk, 2018). Gifted student in this study was defined as students who were always outstanding in science lessons and needed enrichment. They needed to be treated that could direct them to develop their ability (Kunt \& Tortop, 2017)to solve problems, think creatively, critically, and make decision skills. The education curriculum in Indonesia had been systematically structured in such a way that was in line with the 21st century challenges. The problem was how to apply learning so that the higher competencies of learning contained in the curriculum could be optimally achieved. Several alternative learning strategies had been investigated in order to improve students' abilities in accordance with 21 st century learning frameworks (Barak, 2017; Bråten \& Braasch, 2017; Chu, Reynolds, Tavares, Notari, \& Lee, 2017; Luna Scott, 2015; Qian\& Clark, 2016).Some efforts to facilitate gifted students in mastering higher order thinking skills needed in the 21st century had also been carried out (Alhusaini, 2018; Saregar, Irwandani, Abdurrahman, Parmin, Septiana, Diani, \& Sagala, 2018; Erdimez, Sema, \& Zimmerman, 2017; Ozyaprak, 2016).

In response to pedagogical challenges in 21 st century education, STEMbased learning has become a prevalent practice in schools, colleges, and universities. Gifted students have a tendency to high curiosity (Webb, Gore, Amend, \& DeVries, 2007). The integrated application of STEM based learning will provide opportunities for gifted students to explore and develop their abilities through curiosity (Kim, Roh, \& Cho, 2016). Students especially in Indonesia who have low and medium competence (non-talented students) may like STEM as a separate and not integrated dimension to each other, even some of the non-talented students have the potential to have a career in one of the STEM fields. However, if STEM acts as a form of integration between dimensions in it, then they do not necessarily have the same interests, even they tend to be apathetic towards the implementation of STEM integrated in learning. The findings were obtained based on the results of the survey we conducted. These findings lead to the conclusion that non-talented students will not be interested in integrated STEM implementation. Engagement in STEM across the primary-secondary school transition, colleges, and universities had been widely investigated (Dare, Ellis, \& Roehrig, 2018; Koskinen, Lämsä, Maunuksela, Hämäläinen, \&Viiri, 2018; Basham \&Marino, 2013; Laboy-Rush, 2011; Fairweather, 2008; Tytler, Osborne, Williams, Tytler, \& Cripps, 2008). We need to understand the difference between STEM, integrated STEM Education, and STEM learning strategy definitions. STEM is a curriculum 
based on the idea of educating students in four specific disciplines - science, technology, engineering and mathematics - in an interdisciplinary and applied approach. Rather than teach the four disciplines as separate and discrete subjects, STEM integrates them into a cohesive learning paradigm based on real-world applications (Cooper \& Carr, 2018; Hom, 2011). While, integrated STEM education involves the purposeful integration of science, technology, engineering, and mathematics as well as other subject areas through projectbased learning experiences that require the application of knowledge to solve authentic, real-world problems in collaborative environments for the benefit of students (Sandall, Sandall, \& Walton, 2018). STEM education was used to overcome real world situations through problem solving processes. Problems related to real world context can be overcome with design-based solutions (Williams, 2011). STEM education had the potential to contribute to student learning, their lives, and the global economy (Roberts \& Cantu, 2012). However, integrated-STEM implementation had not shown practical packaging and could not reach all the skills needed in the 21 st century, especially to serve gifted students needs. For example, in the research conducted by Rasul, Halim, \& Iksan (2016) and Khalil \& Osman (2017), he did reveal the impact of implementing STEM integrated in learning about 21st century capabilities, but the components of 21 st century capabilities investigated only included digital age literacy, inventive thinking, effective communication, and high productivity, and spiritual values as additional components. Even though the 21 st century capabilities needed include a wider component. Whereas, the education field should provide STEM learning program that was enriched to serve gifted students inside or outside school (Steenbergen-Hu\& Olszewski-Kubilius, 2017). Student learning objectives leading on STEM education were improving performance in science and mathematics (Norton, 2008), increasing STEM literacy (DeCoito\&Richardson, 2016), and improving technological literacy (Rogers, 2005). There was reasonable evidence to assume that some of these goals could be achieved, for example mathematical achievements had been noted to be improved when taught in a technological context (Norton, 2008). The integration of STEM disciplines in the classroom created a learning environment that could increase students' motivation to learn and enhance specific discipline content learning (Riskowski et al., 2009). The concept should also be applied to gifted students. The learning process might provide a makerspace for gifted students to explore their abilities that were superior to other students, so that the achievement of the application of STEM in learning for gifted students could be optimally achieved. However, no recent research had investigated the potential for developing the learning process through STEM to further boost the ability of gifted students.

The main perspective of STEM education refers to the conclusion that the learning approach was student-centered. The concept of this point of view was 
like an inquiry-based approach, where the inquiry approach was oriented to fostering student inquiry skills through active experimentation (Tytler et al., 2014). When learning a topic that was integrated with STEM, the most important activity components are data analysis (Park, Park, \& Bates, 2018), interpretation reflection (Tofel-Grehl, Feldon, \& Callahan, 2018), and critical reflection (Koch, Kucsera, Angus, Norman, Bowers, Nair, \& Barua, 2018). These three components are in the inquiry-based learning approach (Kapelari, 2017). STEM could be integrated in inquiry-based learning (Johns \& Mentzer, 2016). In fact, developing inquiry-based STEM learning could improve the positive attitude of educators towards the teaching and learning of STEM content (DeCoito \& Richardson, 2018).Even, especially for gifted students, inquiry-based matches the special educational needs of gifted students, because it corresponds with their behaviour. Gifted students have many questions, are curious, have unusual ideas etc (Trna, 2014). On the basis of this rationality, the development of an STEM-based learning strategy needed to be carried out until the end point was derived sequentially, student activities that could improve students' abilities in accordance with the dimensions of the STEM education goals.

The efforts of researchers in developing an inquiry-based strategy that was integrated with STEM was an excellent potential to face the challenges of the 21 st century. However, it needs to be understood together that the essence of the application of STEM was different. The concept of inquiry-based STEM learning development strategy in this study focuses on integrated STEM types.Two characteristics of an integrative STEM approach were multidisciplinary and interdisciplinary integration (Wang et al., 2011). Multidisciplinary integration asked students to link content from various subjects taught at different times. Meanwhile, interdisciplinary integration began with real-world problems by combining a cross-curricular content with critical thinking, problem solving skills, and knowledge to reach a conclusion. In the integrated STEM approach, students are required to be able to better understand technology. Therefore, in the learning process based on the STEM approach students will need the types of tools and materials that can help students to carry out the investigation process related to solutions to real-world problems. Materials could include construction tools such as saws, gauges, and hammers; electronic materials such as computers, design programs, robotic kits, and calculators; and other materials used in the design, which can include wood, styrofoam, glue, cardboard, or construction paper. Through the use of these materials in design activities, students can better understand technology. For authentic learning to occur, students must be given the opportunity to design processes or products. The integrated STEM approach was an effort to combine science, technology, engineering, and mathematics into a class based on the relationship between learning material and real-world problems. 
However, in general, integrated STEM education can involve many classes and teachers and does not necessarily involve all four STEM disciplines. So, in each phase of learning, it can contain one or more STEM disciplines or even the entire STEM discipline. Technical discipline could provide students with great problem-solving opportunities to learn about mathematics, science, and technology while working through the engineering design process (Stohlmann et al., 2012). Because several studies that have been described previously have not shown satisfactory results to embrace all 21 st century abilities needed by gifted students, then there needs to be a new strategic alternative that can require gifted students to master the skills needed in the 21 st century comprehensively. So, STEM was seen as a potential practical solution for the development of the quality of future gifted eduacation especially in $21^{\text {st }}$ century era, then the effort to combine STEM-based strategies into the learning process needs to be considered. The purpose of this study was to develop an inquirybasedSTEM learning strategy design for primary education that could systematically guide instructors or designers in creating an appropriate learning activities oriented to 21 st century skills.

\section{Method}

The whole of this research was carried out based on ADDIE development model consisting of Analysis, Design, Development, Implementation, and Evaluation (Jones, 2014)like in the figure 1. This study focused on two of the three types of development of an instructional design namely the development model and the validation model. The instructional design model could be developed through a theoretical or empirical approach, or both. In this study, we used a theoretical approach in developing learning strategies (Richey \& Klein, 2007). 


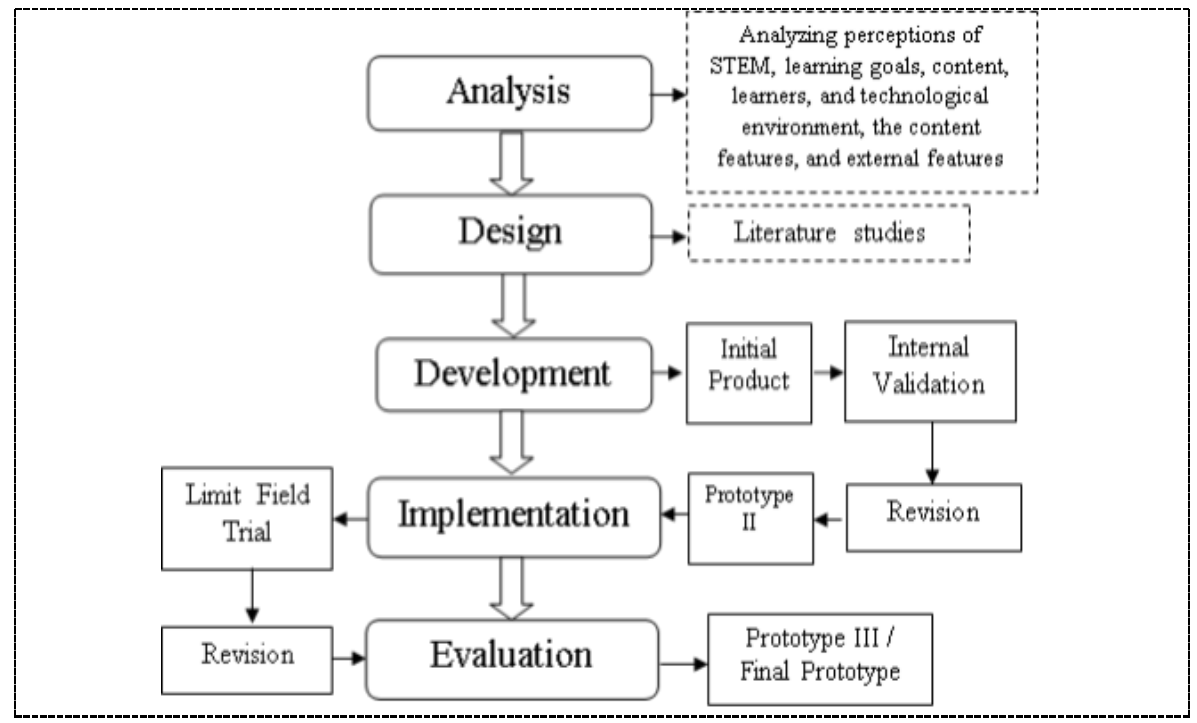

\section{Figure 1.}

Development Stages according to Modified ADDIE

In the analysis phase, we used STEM-based Education and Career Perceptions (STEM EdCaP) instrument using web-based surveys technique (Sills \& Song, 2002) with a multidimensional scale (Kornblau,1982) that we developed to describe teacher and practitioner perceptions about STEM education and careers dimension (Norman, Moore, \& Kern, 2010; Little \& de la Barra, 2009; Cole \& Espinoza, 2008; Rose, 2007). The survey instrument consisted of 22 statements with the type of response that were strongly agree, agree, disagree, and disagree. The survey respondents were 75 professional teachers with S-1 and S-2 educational backgrounds from different science disciplines. The sampling technique was purposive sampling (Guarte\& Barrios, 2006). The second step of the study involved mapping specific design found in inquiry-based learning approach and STEM-based learning strategy literature.The third step of the study involved presenting the synthesis of the previous step to an inquiry-based STEM learning strategy. In this step, we develop learning strategies in accordance with the learning approach chosen. Then we conducted validation and design revision. Evaluation with experts was carried out by using a questionnaire to review the model in terms of substance and construct. The data from the survey and expert validation were analyzed using qualitative descriptive analysis techniques. The limit field trials was conducted in 30 students of senior high school in Lampung. The design of implementation was one-group pretest posttest design (Creswell \& Creswell, 2017). The test instruments used in the pilot study was Newton's STEM Challenge Test instrument. Final revision and evaluation were conducted based on findings in limit field trials. The data analysis technique for estimating 
reliability of this instrument used an internal consistency estimation technique with the Chronbach-alpha formula that was assisted by IBM SPSS 20. If the value of Cronbach's Alpha is 0.60 and less than 1, then the instrument was reliable. Whereas if the value of Cronbach's Alph was below 0.50 down, the instrument was unreliable (Basuki \& Hariyanto, 2014; Al-Kabani, 2004). Validity test was conducted by using the Product Moment Pearson formula. Analysis of product validity was analyzed using SPSS Statistics 17 . The results of the analysis in the form of a correlation coefficient were then interpreted using the degree of validity of the evaluation criteria according to Guilford (1956), where $0.90<\mathrm{r}_{\mathrm{xy}} \leq 1.00$ was interpreted as very high correlated (very valid), $0.70<\mathrm{r}_{\mathrm{xy}} \leq 0.90$ was interpreted to be highly correlated (valid), $0.40<$ $r_{x y} \leq 0.70$ means moderate correlation (quite valid), $0.20<r_{x y} \leq 0.40$ was interpreted as low correlated (less valid), $0.00<\mathrm{r}_{\mathrm{xy}} \leq 0.20$ means very low correlation (very less valid), and $r_{x y} \leq 0.00$ means not correlated (invalid).

\section{Result}

Teachers perceptions of STEM

The development of inquiry-based STEM learning strategy began with an analysis of the results of a survey of teachers 'and practitioners' perceptions of STEM education and STEM career to describe the the urgency of STEM-based inquiry learning (Nadelsonet al.,2013). The Cronbach Alpha Reliability Coefficient of the Likert-type questionnaire was found to be 0.74 which indicated that the instrument was reliable. While, the validity of each item was more than 0.70 which means all items had to be valid. Based on the survey results, it can be indicated teachers have a good perception of STEM education and careers, because the average percentage of respondents' responses on some positive items was more than $50 \%$ (see in the table 1). 
Table 1.

The Sample of Survey Results of STEM Education and Career

\begin{tabular}{lll}
\hline Item Survey & \multicolumn{2}{c}{ Percentage of Responses } \\
\cline { 2 - 3 } & Favourable (\%) & Unfavourable (\%) \\
\hline $\begin{array}{l}\text { STEM is a very } \\
\text { important field for me. }\end{array}$ & 69.3 & 30.7 \\
\hline $\begin{array}{l}\text { I will enjoy working in } \\
\text { the STEM field so }\end{array}$ & 69.3 & 30.7 \\
$\begin{array}{l}\text { much. } \\
\text { Taking STEM classes } \\
\text { will be so fun for me. }\end{array}$ & 72.0 & 28.0 \\
\hline
\end{tabular}

\section{The initial product design}

The sequential mapping of learning activities derivatives was obtained based on theoretical rationality that still refer to the empirical results of survey data (see table 2). The rationality of learning sequential derivatives was integrated to produce a strategy namely GUIDANCE (Generating motivation and interest in science, Upraising curiosity, In depth Discussion, Analyzing, arraNging, and Constructing idEas).

\section{Table 2.}

Strategy Sequential Mapping in an Inquiry-Based Learning Approach

\begin{tabular}{cll}
\hline Phase & Inquiry-based Learning Approach & Strategy Sequential \\
\hline 1 & Discovery learning & $\begin{array}{l}\text { Generating motivation } \\
\text { and interest in science }\end{array}$ \\
\hline
\end{tabular}

Rationality of learning motivation should be considered because student learning motivation was a very important element to be able to master the STEM discipline integrated into learning (Skinner et al., 2017). In addition to the dimensions of motivation, interest also provided an important role to achieve successful learning oriented to the STEM discipline, because the level of success of students in participating in learning that contains STEM discipline was strongly influenced by students' interest in STEM (Bottia et al., 2018). To optimize the learning success of students oriented to STEM, it could begin by increasing students' interest and motivation towards STEM through the context of science. By giving students a form of experience through science, students could develop concepts independently and define terms. The experience might be able to raise students' motivation and interest towards STEM, so that students had a perception that they were able to explore the potential they have through STEM, and science was the beginning of what they will learn. 


\section{Phase Inquiry-based Learning Approach Strategy Sequential

2 Interactive demonstration Upraising curiosity \\ Rationality to increase curiosity in the interactive demonstration phase was based on the fact that one of the basic concepts of STEM was curiosity (Reighard et al., 2016). Curiosity could be increased through student learning activities that were not only "hands on activities" but rather "minds on experience," it would help students to gain an understanding of concepts and also increase curiosity that was more than the previous learning phase. The role of the teacher was very important to provide learning experiences that encourage students' natural imagination and curiosity through direction and guidance (Katz \& Chard, 2000). In the context of the interactive demonstration learning phase, a form of direction to provide experiences to students could be conduct by teacher demonstrations. So the integration of STEM disciplines, especially science and technology could be contained in this learning phase when the teacher provided a modeling of scientific procedures to students. Through demonstration, students would build alternative concepts based on the experience gained in the previous learning phase. Modeling and demonstration carried out by having to ask students could get conclusions about a concept based on evidence, the success of students to identify the truth of their alternative concepts had the potential to increase students' curiosity.}

\begin{tabular}{ll}
\hline 3 & Inquiry lesson \\
\hline & The rationality in this learning phase was based on the study result \\
which stated that to optimize the STEM discipline in learning the \\
teacher could apply inquiry-based lessons, where the teacher could \\
act as a facilitator (Urban et al., 2018). When students formulated an \\
experimental design independently, the activity would be more \\
meaningful with class discussion. Inquiry instructions containing \\
discussions had been investigated could potentially improve STEM- \\
based learning (Marshall et al., 2009). The final goal in this phase \\
required students to be able to simulate a form of experiment to \\
identify variables embedded by the role of science and mathematics \\
discipline in their experiments. The teacher could help students \\
through in depth discussion activities where students and teachers \\
conduct in-depth discussions about the design of the experiment to \\
reach at the achievement of the learning goals. \\
\hline Inquiry labs \\
Analyzing activity was a fundamental component of the inquiry lab
\end{tabular}




\section{Phase Inquiry-based Learning Approach Strategy Sequential}

phase (Remsburg et al., 2014). In the inquiry labs phase, students developed and carried out experiments and collect appropriate data. The results of the experimental data were then analyzed to find a law that explains the exact relationship between variables. The Inquiry Labs and STEM could not be separated because the development of the inquiry labs phase could be an innovation in the application of STEM in learning (de Jong et al., 2014). In this phase, STEM discipline could be raised to assist students in analyzing and interpreting the empirical data obtained. One of the STEM disciplines that emerge besides engineering discipline and mathematics was technology (Lynch \& Ghergulescu, 2017). The role of the teacher in this phase was to provide assistance to students who experience difficulties. All activities and learning activities in this phase are the responsibility of students.

\begin{tabular}{l} 
Real-world applications \\
\hline An integrated STEM education was defined as an attempt to \\
combine several or all of the four disciplines of science, technology, \\
engineering, and mathematics into one class, unit, or lesson based \\
on the relationship between subject and real world problems \\
(Moore et al., 2014). Making connections between STEM \\
disciplines was complex and required teachers to teach STEM \\
content in a deliberate way. Therefore, authors used the word \\
"arranging" as a derivative of student activity, because students were \\
required to be able to apply the knowledge that had been obtained \\
in situations or problems in the real world. The process of applying \\
in this phase could be started by designing a solution related to real- \\
world situations or problems so that students understand how \\
STEM knowledge was integrated.
\end{tabular}

6 Hypothetical inquiry Constructing ideas

In this phase, students were guided to develop an explanation of why things or how the working principle of a system was in the context of the real world by applying the knowledge previously obtained. To be able to achieve that process, students needed to construct ideas to explain or predict about things that would happen from the situation in the real world context. The role of STEM in this phase was the same as the previous phase where the whole STEM was integrated. Ideas were the power of inquiry at the highest level (Berger, 2014).Therefore, researchers put the component of ideas in the hypothetical inquiry learning phase, because in this phase the student's knowledge of the end of the 


\section{Phase Inquiry-based Learning Approach Strategy Sequential}

level also reached the highest level.

Then we continued to the developing step. Developing step lead to explore GUIDANCE strategy contains core learning activities that must be carried out by teachers and students. Finally, the initial product or prototype I was obtained to be validated. Indeed in the sequential arrangement of activities we develop based on the needs of students at the basic competency level. However, the application of each sequential developed is oriented towards learning activities that are not only needed by students in general, but are more focused on the needs of gifted students

\section{Internal validation (expert review)}

The expert review consisted of one professor and one doctoral from a variety of disciplines (educational technology and physics), all with experience in the design and theoretical expertise of inquiry-based STEM leaning strategy. They were asked to evaluate the validity of initial strategy design in terms of content and contruct dimension. Mean scores ranged from 2.8 to 3.8 on a scale of 4 to 1 , with 4 indicating "strongly agree" and 1 indicating "strongly disagree". The content validity index (CVI) and interrater agreement (IRA) was higher than 0.80 for all items, indicating that the validity of the model was acceptable (Davis, 1992; Lynn, 1986), and experts' evaluation were mostly in agreement about the usefulness of the model. Revision was conducted after mapping the experts suggestions. Finally, the second prototype was obtained.

The final product design

The final inquiry-based STEM learning strategy design was obtained after revising process bases on external validity results. The final product were presented in Table 3. 
Table 3.

Students' and Teachers' Activities in GUID ANCE Learning Strategy

\begin{tabular}{|c|c|c|c|}
\hline $\begin{array}{l}\text { Inquiry } \\
\text { Learning } \\
\text { Phase }\end{array}$ & $\begin{array}{l}\text { Guidanc } \\
\text { e } \\
\text { Learning } \\
\text { Strategy }\end{array}$ & Core Activities & STEM Integration \\
\hline \multirow{4}{*}{$\begin{array}{l}\text { Discovery } \\
\text { learning }\end{array}$} & \multirow{4}{*}{$\begin{array}{l}\text { Generatin } \\
\mathrm{g} \\
\text { motivatio } \\
\mathrm{n} \text { and } \\
\text { interest in } \\
\text { science }\end{array}$} & The teacher & Science \\
\hline & & $\begin{array}{l}\text { shows the First } \\
\text { Hand } \\
\text { Experiences }\end{array}$ & $\begin{array}{l}\text { - Starting with the question of } \\
\text { a phenomenon. } \\
\text { - Experiences must be } \\
\text { attractive and new for } \\
\text { students. }\end{array}$ \\
\hline & & $\begin{array}{l}\text { Students } \\
\text { develop } \\
\text { concepts and } \\
\text { define terms }\end{array}$ & $\begin{array}{l}\text { Science } \\
\text { - Using a model to develop an } \\
\text { explanation of the experience } \\
\text { through problem posing. }\end{array}$ \\
\hline & & $\begin{array}{l}\text { The teacher } \\
\text { raises students' } \\
\text { motivation and } \\
\text { interests }\end{array}$ & $\begin{array}{l}\text { Science } \\
\text { - Building students' motivation } \\
\text { and interest in science } \\
\text { through soft scaffolding. }\end{array}$ \\
\hline \multirow[t]{2}{*}{$\begin{array}{l}\text { Interactive } \\
\text { demonstra } \\
\text { tion }\end{array}$} & \multirow[t]{2}{*}{$\begin{array}{l}\text { Upraising } \\
\text { curiosity }\end{array}$} & $\begin{array}{l}\text { The teacher } \\
\text { demonstrates } \\
\text { experiments } \\
\text { \&models } \\
\text { scientific } \\
\text { procedures }\end{array}$ & $\begin{array}{l}\text { Science } \\
\text { - Understanding problems and } \\
\text { things that might need to be } \\
\text { scientifically investigated. } \\
\text { Technology } \\
\text { - Identifying criteria, } \\
\text { limitations, specification } \\
\text { problems with technology } \\
\text { approaches. }\end{array}$ \\
\hline & & $\begin{array}{l}\text { Creating } \\
\text { interactive } \\
\text { learning by } \\
\text { using probing } \\
\text { questions. }\end{array}$ & $\begin{array}{l}\text { Science } \\
\text { - Generating questions that } \\
\text { can be investigated. } \\
\text { Technology } \\
\text { - Conducting investigation for } \\
\text { the purpose of designing } \\
\text { applications. }\end{array}$ \\
\hline Inquiry & In depth & The teacher & Engineering \\
\hline lesson & $\begin{array}{l}\text { Discussio } \\
\mathrm{n}\end{array}$ & $\begin{array}{l}\text { helps students } \\
\text { to formulate an } \\
\text { experimental } \\
\text { approach. }\end{array}$ & $\begin{array}{l}\text { - Starting with problems, } \\
\text { needs, or desires that lead to } \\
\text { - engineering solutions. } \\
\text { Mathematics }\end{array}$ \\
\hline
\end{tabular}


- Model with mathematics

\begin{tabular}{|c|c|c|}
\hline & & - $\quad$ Model with mathematics \\
\hline & $\begin{array}{l}\text { Students } \\
\text { conduct in- } \\
\text { depth } \\
\text { discussions to } \\
\text { formulate } \\
\text { experimental } \\
\text { designs to } \\
\text { identify } \\
\text { variables }\end{array}$ & $\begin{array}{l}\text { Engineering } \\
\text { - Using models and } \\
\text { simulations to analyze } \\
\text { existing solutions. } \\
\text { Mathematics } \\
\text { - Designing the right tools } \\
\text { strategically. }\end{array}$ \\
\hline & $\begin{array}{l}\text { Students } \\
\text { demonstrate } \\
\text { how to conduct } \\
\text { controlled } \\
\text { experiments. }\end{array}$ & $\begin{array}{l}\text { Engineering } \\
\text { - Conducting technical } \\
\text { investigation modeling. } \\
\text { Science } \\
\text { - Carry out scientific } \\
\text { procedures. }\end{array}$ \\
\hline \multirow[t]{3}{*}{ Inquiry lab Analyzing } & $\begin{array}{l}\text { Students } \\
\text { conduct } \\
\text { experiments and } \\
\text { collect } \\
\text { appropriate } \\
\text { data. }\end{array}$ & $\begin{array}{l}\text { Engineering } \\
\text { - Investigating techniques to } \\
\text { get the data needed to } \\
\text { identify criteria and } \\
\text { constraints and to test design } \\
\text { ideas. } \\
\text { Technology } \\
\text { - Applying the model. }\end{array}$ \\
\hline & $\begin{array}{l}\text { Students analyze } \\
\text { data to find the } \\
\text { right } \\
\text { relationship } \\
\text { between } \\
\text { variables. }\end{array}$ & $\begin{array}{l}\text { Science \& Mathematics } \\
\text { - } \quad \text { Interpreting data - creating } \\
\text { an abstraction of a situation } \\
\text { and representing it as a } \\
\text { symbol and manipulating. }\end{array}$ \\
\hline & $\begin{array}{l}\text { Students } \\
\text { communicate } \\
\text { results. }\end{array}$ & $\begin{array}{l}\text { Technology \& Science } \\
\text { - Scientifically explain failures } \\
\text { and design improvement } \\
\text { solutions with the help of } \\
\text { technology. }\end{array}$ \\
\hline $\begin{array}{l}\text { Real-world arranging } \\
\text { application }\end{array}$ & $\begin{array}{l}\text { Students design } \\
\text { solutions for } \\
\text { real-world } \\
\text { problems or } \\
\text { situations. }\end{array}$ & $\begin{array}{l}\text { Science, Technology, } \\
\text { Engineering, \& Mathematics } \\
\text { - Investigating techniques with } \\
\text { experiment-goals, } \\
\text { mathematical modeling, } \\
\text { managing variables, accurate }\end{array}$ \\
\hline
\end{tabular}




\begin{tabular}{|c|c|c|}
\hline & \multicolumn{2}{|r|}{$\begin{array}{l}\text { observation and } \\
\text { measurement, \& seeing } \\
\text { patterns. }\end{array}$} \\
\hline & $\begin{array}{l}\text { Students } \\
\text { conduct project- } \\
\text { based problem } \\
\text { solving }\end{array}$ & $\begin{array}{l}\text { Science, Technology, } \\
\text { Engineering, \& Mathematics } \\
\text { - } \text { Building design solutions } \\
\text { using a systematic approach } \\
\text { to solving engineering } \\
\text { problems based on scientific } \\
\text { knowledge and the material } \\
\text { world model. The designed } \\
\text { solution is optimized by } \\
\text { balancing the constraints and } \\
\text { criteria of the existing } \\
\text { conditions. }\end{array}$ \\
\hline & $\begin{array}{l}\text { Students } \\
\text { understand the } \\
\text { application of } \\
\text { prior knowledge } \\
\text { through } \\
\text { multiple } \\
\text { representations. }\end{array}$ & $\begin{array}{l}\text { Science, Technology, } \\
\text { Engineering, \& Mathematics } \\
\text { - Expressing order in repeated } \\
\text { reasoning in the form of } \\
\text { multiple representations. }\end{array}$ \\
\hline $\begin{array}{ll}\text { Hypotheti } & \text { Construct } \\
\text { cal inquiry } & \text { ing ideas }\end{array}$ & $\begin{array}{l}\text { Build ideas for } \\
\text { new authentic } \\
\text { problems }\end{array}$ & $\begin{array}{l}\text { Science, Technology, } \\
\text { Engineering, \& Mathematics } \\
\text { Communicate ideas, design } \\
\text { decisions, justifications, } \\
\text { scientific explanations, and } \\
\text { establish practical design } \\
\text { rules. }\end{array}$ \\
\hline
\end{tabular}

\section{The Pilot Study}

The limit field trial as a pilot study was done in high school in Lampung as many as three session per experiment class with the allocation of 3 hours per meeting consisting of 45 minutes per hour. The implementation of GUIDANCE-STEM inquiry based learning stategy involved 30 senior high students. More than 75 percent of the students we made as research subjects were gifted students. The result of this implementation step in the form of quantitative data consisted of mastery concepts and higher order thinking skills data of learners with the strategy developed on the Gravitation Newton Law concepts acquisition. Higher order thinking skills included the skills in solving the problems through inquiry phase embedded with STEM strategy. Results of this research processed using software SPSS 21.0 application. The normality 
and homogenity test indicated that the data pretest and posttest met the criteria for normally and homogen distributed data with $\mathrm{p}$-value $>0.05$. The test was continued to paired sample t test. The analysis result showed that the strategy developed could significantly increases student's mastery concepts and higher order thinking skills regading to Gravitation Newton Law topics with $p$-value $=$ 0.00 .

Furthermore, in order to prove the extent of the impact effect the STEM learning startegy in improving students' understanding about Newton's Law of Motion, we conducted experiment quasi of non equivalent control group pretest and posttest design which involved two gifted student groups which included 35 senior high school students as a experiment class and 32 students of control class. The students in experimental group have taught using GUIDANCE-STEM inquiry based learning strategy while the students in control class have taught by the scientific approach. The application of STEM in learning with the topic of Newton's Law of motion was realized by making miniature cars with the concept of restoring force. The results showed that the effect size score was higher of 0.24 which means the product gave impact to the learning process in a medium category. Beside, the extended pilot study result showed thatthe normalize gain ( $\mathrm{N}$-gain) value was intermediate high criteria $(\mathrm{N}$-gain $=0.55$ and 0.49) for experimental group and control group respectively. Recording student activities related to the ability to collaborate, communicate, and other social skills was conducted by using journal learning activities. Based on teacher records, students have demonstrated these abilities with a high percentage, which was above $80 \%$.

\section{Discussion and Conclusion}

The results of teacher perception saw the excellent potential on the application of STEM, because the teacher's perception leads to the conclusion that STEM must be applied and developed in the dimensions of education and career. However, it still seems that there were some respondents' perceptions that lead to negative responses, respondents assumed that STEM education did not need to be applied because of minimal urgency, wasting time in its application, and disinterest.It turned out that negative responses related to the education dimension also appeared in the careers dimension. The respondent's perception leads to a perception that STEM had no potential to serve as a career orientation.Based on these two contradictory results, the researcher tries to draw a red thread from some of the findings that appear that researchers must develop a model of STEM implementation in the field of education that is practical and contains the urgency of STEM in its application.

The initial inquiry-based STEM learning strategy was developed from the synthesis of inquiry learning approach and STEM learning strategy. Design suggestion from survey results and literature study were embedded in the 
design and development step. We analyzed teacher perceptions, learning goals, content, learners, and technological environment, the content features, and external features in analysis step. Design step refered to determining learning approach, designing strategy framework, mapping sequential strategy based on theoretical rationality, and preparing validation instruments. Indeed in the sequential arrangement of activities we develop based on the needs of students at the basic competency level. However, the application of each sequential developed is oriented towards learning activities that are not only needed by students in general, but are more focused on the needs of gifted students. That is, if the strategies we develop are implemented, students in general and those who are gifted will be able to achieve learning goals in accordance with their respective capacities. So, learning that will take place will not limit the gifted students to explore the highest abilities they have.

The content validity index (CVI) and interrater agreement (IRA) was higher than 0.80 for all items, indicating that the validity of the model was acceptable (Davis, 1992; Lynn, 1986), and experts' evaluation were mostly in agreement about the usefulness of the model. Additionally, they felt strongly that a detailed description of the model needed for a simplified manual guidance to be used by teachers. In addition, they believed that guidelines for allocating learning content would be very helpful. Related to this suggestion, authors plan to design a manual guidance on future research that might focus on specific learning materials or topics.

Statistics analysis results of the product showed a good results with very high criteria. The instruments we developed to examine students' understanding of Physics material taught in STEM-integrated learning consisted of indicators of higher order thinking skills (creative and critical thinking), decision making skills, literacy skills, and problem solving skills (Kemdikbud, 2016). In student learning directed at the development of data literacy, technology literacy, and human literacy. Therefore, we dare to express that the strategies we offer are able to embrace the capabilities needed in the 21 st century. The strategy developed could make the participants were encouraged to create a visual form of their own to represent the understanding of the basic concepts that they focus on problem solving authentic or manufacture of the product, including the application of product design, for example, express opinions, creation, testing, repairing aimed at scaling up of understanding of the concept of learners. By learning so much fun as it is, then any learners were given the opportunity to express and carry out their research plans of each to solve problems that would occur gender equality understanding of the concept because in the learning activities of each learner men and women were given opportunities together to think about the concept of science and designing engineering to make the product as the application and use mathematics as a tool. Learning activities in the classroom between men and women creates a 
social interaction which also could reduce gender disparity. The another findings indicated how resulting the strategy instruction impacted students' views of STEM and students' satisfactions in regard to the course overall. The results of external validity lead to several improvements, authors needed to describe the role of STEM in learning in the implementation strategy manual guidance, authors also needed to map the role of STEM at each phase of inquiry learning.

In general, the more specific a model gets, the narrower the application of the model becomes. It became a dilemma when asserting that design requires specificity but specificity is incompatible with reusability and general application (Downes, 2003). The task of finding the best balance between a useful model with specific and practical guidelines and a wide-reaching model with general and flexible guidelines is crucial, but challenging. In the process of internal validation in this study, the experts closer to being practitioners preferred the former approach whereas the experts who were closer to being theorist prefer the latter. The strategy developed in this study was intended for general application within the 21 st century education context, while clearly specifying the meanings of the component steps so that the steps can cognitively guide designers to make intelligent design decisions.

Finally, the main contribution of this study was the STEM learning strategy design which could be used to improve students' 21 st century skills especially higher order thinking skills. The strategy was an inquiry-based STEM learning strategy GUIDANCE (Generating motivation and interest in science, Upraising curiosity, In depth Discussion, Analyzing, arraNging, and Constructing idEas) which was in line with the research that we had carried out before (Abdurrahman, Ariyani, Achmad, \& Nurulsari, 2019; Abdurrahman, 2019). This strategy was feasible to be applied in the learning process, it had been designed to be able to explore student's problem solving skill and other higher order thinking skills which was part of 21 st century skills. This study may be limitted in that the strategy design was developed from a single case, suggesting the need for confirmation in more cases. Also, since the case was a Heat course, the strategy may include some features relevant to courses in natural sciences but not to other disciplines which may require different design processes. Further, even though the strategy design in this study underwent internal validation from experts from diverse disciplines, actual implementation of the strategy in courses in these fields might reveal different aspect of strategy design. 


\section{Biodata of the Authors}

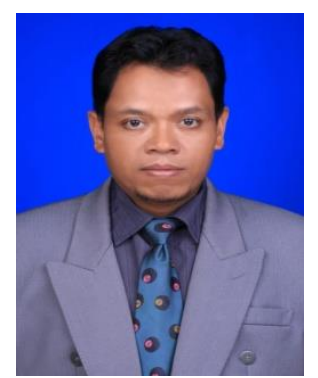

Abdurrahman was born in Rangkasbitung, Indonesia. He completed his high school education at The First Rangkasbitung Public High School in 1988. He graduated from Department of Science Education, Graduate School of Indonesia University of Education in 2010. He is an assistant professor, Department of Mathematics and Science Education, Faculty of Teacher Training and Education, Lampung Province, Indonesia. His research focuses on science teacher education, science teaching and learning, STEM education and literacy, problem-based learning, project-based learning, and multimodal representations in science learning.

Affiliation: Department of Science Education, Faculty of Teacher Training and Education, University of Lampung, Bandar Lampung, Lampung Province, Indonesia.

E-mail: abdurrahman.1968@,fkip.unila.ac.id.

Phone: (+62)8127911494

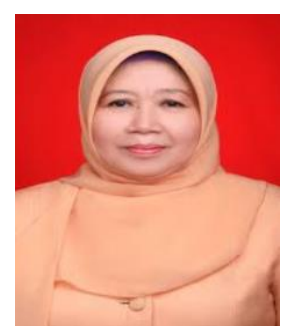

Farida ARIYANI was born in Pringsewu, Indonesia. She graduated from Linguistic Education Department at Lampung University in 1978, then continue to master program in Linguistic Education Department at Malang State University in 1984. She completed her doctoral program in Literature Department at Padjajaran University in 2009. She is a lecture in Lingusitic Education Department of Teacher Training and Education Faculty, Lampung Province, Indonesia. Her research focuses on linguistic education, linguistic teaching and learning, and literacy.

Affiliation: Department of Linguistic Education, Faculty of Teacher Training and Education, University of Lampung, Bandar Lampung, Lampung Province, Indonesia.

E-mail: dulifarida@gmail..com

Phone: (+62)81279152999

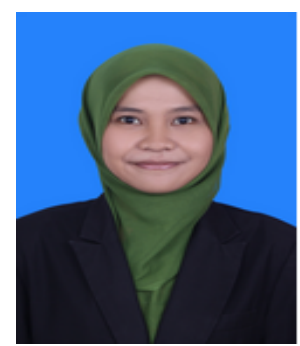

Hervin MAULINA was born in Pakuan Ratu, Indonesia. She completed her high school at The Senior High School State 1 Kotagajah in 2008. She graduated from Department of Science Education Lampung University in 2012, then continue to master programe at physics deprtement of Universitas Gadjah Mada in 2012-2014. She is a lecture in Science Education Department of Teacher Training and Education Faculty, Lampung Province, Indonesia. Her research focuses on optical physics, computational physics, physics teacher education, and physics teaching and learning. 
Affiliation: Department of Science Education, Faculty of Teacher Training and Education, University of Lampung, Bandar Lampung, Lampung Province, Indonesia.

E-mail: hervin.maulina@staff.unila.ac.id

Phone: (+62)85669937997

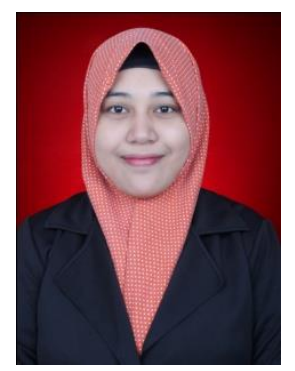

Novinta NURULSARI was born in Bandar Lampung, Indonesia. She completed her high school education at The First Bandar Lampung Public Islamic High School in 2011. She completed her undergraduted in the field of Physics Education at Lampung University in 2015. She received her Master's degree in the field of Physics Education at Lampung University in 2017. She is a lecture in Science Education Department of Teacher Training and Education Faculty, Lampung University, Indonesia. Her research focuses on science education, science teaching and learning, STEM education, and scaffolding.

Affiliation: Department of Science Education, Faculty of Teacher Training and Education, University of Lampung, Bandar Lampung, Lampung Province, Indonesia.

E-mail: novinta.nurulsari@,fkip.unila.ac.id.

Phone: (+62)85609592777 


\section{References}

Abdurrahman, Ariyani, F., Achmad, A., \& Nurulsari, N. (2019). Designing an Inquirybased STEM Learning Strategy as a Powerful Alternative Solution to Enhance Students' $21^{\text {st }}$ Century Skills: A Preliminary Research. In Journal of Physics: Conference Series (Vol. 1155, No. 1, p. 012087). IOP Publishing.

Abdurrahman. (2019). Developing STEM Learning Makerspace for Fostering Student's $21^{\text {st }}$ Century Skills in The Fourth Industrial Revolution Era. In Journal of Physics: Conference Series (Vol. 1155, No. 1, p. 012002). IOP Publishing.

Alhusaini, A. A. (2018). Using the TASC Model to Develop Gifted Students' Creativity: Analytical Review. Journal for the Education of Gifted Young Scientists, 6(3), 11-29.

Al-Kalbani, Nora Rashed (2004). Omani English Teachers' and Students' Perceptions of the Role of Grammar Instruction in EFL Teaching and Learning Unpublished Thesis. Sultan Qaboos University

Barak, M. (2017). Science teacher education in the twenty-first century: a pedagogical framework for technology-integrated social constructivism. Research in Science Education, 47(2), 283-303.

Basham, J. D., \& Marino, M. T. (2013). Understanding STEM education and supporting students through universal design for learning. Teaching Exceptional Children, 45(4), 8-15.

Basuki, I., \& Hariyanto. (2014). Asesemen pembelajaran. Bandung: PT. Remaja Rosdakarya.

Berger, W. (2014). A more beautiful question: The power of inquiry to spark breakthrough ideas. Bloomsbury Publishing USA.

Bottia, M. C., Stearns, E., Mickelson, R. A., \& Moller, S. (2018). Boosting the numbers of STEM majors? The role of high schools with a STEM program. Science Education, 102(1), 85-107.

Bråten, I., \& Braasch, J. L. (2017). Key issues in research on students' critical reading and learning in the 21 st century information society. In Improving reading and reading engagement in the 21st century (pp. 77-98). Springer, Singapore.

Chu, S. K. W., Reynolds, R. B., Tavares, N. J., Notari, M., \& Lee, C. W. Y. (2017). Twenty-first century skills education in Switzerland: An example of project-based learning using Wiki in science education. In 21st Century Skills Development Through Inquiry-Based Learning (pp. 61-78). Springer, Singapore.

Cole, D., \&Espinoza, A. (2008). Examining the academic success of Latino students in science, technology, engineering, and mathematics (STEM) majors. Journal of College Student Development, 49(4), 285-300.

Cooper, G., \& Carr, N. (2018). Primary Pre-Service Teachers' Perceptions of STEM Education: Conceptualisations and Psychosocial Factors. In STEM Education: $A n$ Emerging Field of Inquiry (pp. 167-189). Brill Sense

Creswell, J. W., \& Creswell, J. D. (2017). Research design: Qualitative, quantitative, and mixed methods approaches. Sage publications.

Dare, E. A., Ellis, J. A., \& Roehrig, G. H. (2018). Understanding science teachers' implementations of integrated STEM curricular units through a phenomenological multiple case study. International Journal of STEM Education, 5(1), 4.

Davis, L. L. (1992). Instrument review: getting the most from your panel of experts. Applied Nursing Research, 5(4), 194-197.

de Jong, T., Sotiriou, S., \& Gillet, D. (2014). Innovations in STEM education: the GoLab federation of online labs. Smart Learning Environments, 1(1), 3.

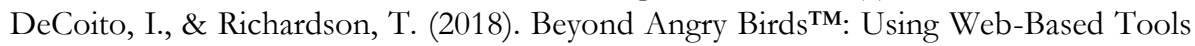
to Engage Learners and Promote Inquiry in STEM Learning. In Information and Technology Literacy: Concepts, Methodologies, Tools, and Applications (pp. 410-433). IGI Global. 
DeCoito, I., \& Richardson, T. (2016). Using Technology to Enhance Science Literacy, Mathematics Literacy, or Technology Literacy: Focusing on Integrated STEM Concepts in a Digital Game. In Improving K-12 STEM Education Outcomes Through Technological Integration (pp. 1-22). IGI Global.

Downes, S. (2003). Design and reusability of learning objects in an academic context: a new economy of education?. Journal of the United States Distance Learning Association, 17(1), 3-22.

Erdimez, Ö., Sema, T. A. N., \& Zimmerman, R. (2017). The Use of Concept Maps as a Tool to Measure Higher Level Thinking Skills in Elementary School Science Classes. Journal for the Education of Gifted Young Scientists, 5(2), 1-20.

Fairweather, J. (2008). Linking evidence and promising practices in science, technology, engineering, and mathematics (STEM) undergraduate education. Board of Science Education, National Research Council, The National Academies, Washington, DC.

Guarte, J. M., \& Barrios, E. B. (2006). Estimation under purposive sampling.

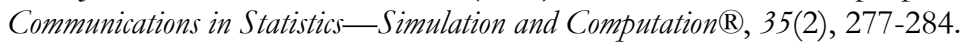

Guilford, J.P. (1956). Fundamental Statistic in Psychology and Education. 3rd Ed. New York: McGraw-Hill Book Company, Inc

Hom, Elaine J. (2011). What is STEM Education?. Retrieved from: https://www.livescience.com/43296-what-is-stem-education.html

Johns, G., \& Mentzer, N. (2016). STEM integration through design and inquiry. Technology and Engineering Teacher, 76(3), 13.

Jones, B. A. (2014). ADDIE Model (Instructional Design). Retrievedfrom http://citeseerx.ist.psu.edu/viewdoc/summary?doi=10.1.1.572.4041.

Kapelari, Suzanne. (2017). Inquiry Learning in STEM Subjects. Retrieved from https://www.phnoe.ac.id.at/fileadmin/root_phnoe/International/files/Kapelari_I nquiry_Learning.pdf.

Katz, L. \& Chard, S. (2000). Engaging Children's Minds: The Projects Approach, 2nd ed. Stamford, CT: Ablex.

Kementerian Pendidikan dan Kebudayaan Republik Indonesia (Kemdikbud), 2016, Jendela Pendidikan dan Kebudayaan, Avalaible at https://jendela.data.kemdikbud.go.id/

Khalil, N. M., \& Osman, K. (2017). STEM-21CS module: Fostering 21st century skills through integrated STEM. K-12 STEM Education, 3(3), 225-233.

Kim, M. K., Roh, I. S., \& Cho, M. K. (2016). Creativity of gifted students in an integrated math-science instruction. Thinking Skills and Creativity, 19, 38-48.

Koch, R., Kucsera, J., Angus, K. B., Norman, K., Bowers, E., Nair, P., \& Barua, S. (2018). Enhancing learning power through first-year experiences for students majoring in STEM disciplines. Journal of STEM Education, 19(1), 22-30

Kornblau, B. (1982). The teachable pupil survey: A technique for assessing teachers' perceptions of pupil attributes. Psychology in the Schools, 19(2), 170-174.

Koskinen, P., Lämsä, J., Maunuksela, J., Hämäläinen, R., \& Viiri, J. (2018). Primetime learning: collaborative and technology-enhanced studying with genuine teacher presence. International Journal of STEM Education, 5(1), 20.

Kunt, K., \& Tortop, H.S. (2017). Examination of Science and Technology Teachers' Attitude and Opinions Related Giftedness and Gifted Education in Turkey. Journal for the Education of Gifted Young Scientists, 5(1), 37-54.

Laboy-Rush, D. (2011). Integrated STEM education through problem-based learning.[White paper]. Education through Project-Based Learning. Retrieved frorn http://www. slideshare. net/dlaboyrush/integrating-Stern.

Little, A. J., \& de la Barra, B. A. L. (2009). Attracting girls to science, engineering and technology: AnAustralian perspective. European Journalof Engineering Education, 34, 439-445. 
Luna Scott, C. (2015). The Futures of Learning 3: What kind of pedagogies for the 21st century?.

Lynch, T., \& Ghergulescu, I. (2017). Review Of Virtual Labs As The Emerging Technologies For Teaching STEM Subjects. In INTED2017 Proc. 11th Int. Technol. Educ. Dev. Conf. 6-8 March Valencia Spain (pp. 6082-6091).

Lynn, M. R. (1986). Determination and quantification of content validity. Nursing research, 35(6), 382-385.

Marshall, J. C., Horton, R., Igo, B. L., \& Switzer, D. M. (2009). K-12 science and mathematics teachers' beliefs about and use of inquiry in the classroom. International Journal of Science and Mathematics Education, 7(3), 575-596.

Moore, T., Stohlmann, M., Wang, H., Tank, K., Glancy, A., \& Roehrig, G. (2014). Implementation and integration of engineering in K-12 STEM education. In S. Purzer, J. Strobel, \& M. Cardella (Eds.), Engineering in Pre-College Settings: Synthesizing Research, Policy, and Practices (pp. 35-60). West Lafayette: Purdue University Press.

Nadelson, L. S., Callahan, J., Pyke, P., Hay, A., Dance, M., \& Pfiester, J. (2013). Teacher STEM perception and preparation: Inquiry-based STEM professional development for elementary teachers. The Journal of Educational Research, 106(2), 157-168.

Norman, K. W., Moore, T. J., \& Kern, A. L. (2010). A graduate level in-service teacher education curriculum integrating engineering into science and mathematics contents. Montana Mathematics Enthusiast, 7(2), 433-446.

Norton, S. (2008) The use of design practice to teach mathematics and science. International Journal of Technology and Design Education, 18(1), 19-44.

Ozyaprak, M. (2016). The effectiveness of SCAMPER technique on creative thinking skills. Journal for the Education of Gifted Young Scientists, 4(1), 31-40.

Park, D. Y., Park, M. H., \& Bates, A. B. (2018). Exploring young children's understanding about the concept of volume through engineering design in a STEM activity: A case study. International Journal of Science and Mathematics Education, 16(2), 275-294.

Qian, M., \& Clark, K. R. (2016). Game-based Learning and 21st century skills: A review of recent research. Computers in Human Behavior, 63(C), 50-58.

Rasul, M. S., Halim, L., \& Iksan, Z. (2016). Using STEM Integrated Approach To Nurture Students' Interest and 21st Century Skills. The Eurasia Proceedings of Educational \& Social Sciences, 4, 313-319

Reighard, C., Torres-Crespo, M. N., \& Vogel, J. (2016). STEM Curiosity Academy: Building the Engineers of Tomorrow. Children and Libraries, 14(4), 32-35.

Remsburg, A. J., Harris, M. A., \& Batzli, J. M. (2014). Statistics across the curriculum using an iterative, interactive approach in an inquiry-based lab sequence. Journal of College Science Teaching, 44(2), 72-81.

Richey, R. C., \& Klein, J. D. (2007). Design and development research. Mahwah: Lawrence Erlbaum.

Riskowski, J. L., Todd, C. D., Wee, B., Dark, M., \& Harbor, J. (2009). Exploring the effectiveness of an interdisciplinary water resources engineering module in an eighth grade science course. International journal of engineering education, 25(1), 181.

Roberts, A., \& Cantu, D. (2012, June). Applying STEM instructional strategies to design and technology curriculum. In PATT 26 Conference; Technology Education in the 21st Century; Stockholm; Sweden; 26-30 June; 2012 (No. 073, pp. 111-118). Linköping University Electronic Press. 
Rogers, G. (2005). Pre-engineering's place in technology education and its effect on technological literacy as perceived by technology education teachers. Journal of Industrial Teacher Education, 41(3), 6-22.

Rose, M. A. (2007). Perceptions of technological literacy among science, technology, engineering, and mathematics leaders. Journal of Technology Education, 19(1), 35-52.

Sandall, B. K., Sandall, D. L., \& Walton, A. L. (2018). Educators' Perceptions of Integrated STEM: A Phenomenological Study. Journal of STEM Teacher Education, 53(1), 3

Saregar, A., Irwandani, I., Abdurrahman, A., Parmin, P., Septiana, S., Diani, R., \& Sagala, R. (2018). Temperature and Heat Learning Through SSCS Model with Scaffolding: Impact on Students' Critical Thinking Ability. Journal for the Education of Gifted Young Scientists, 6(3), 39-54.

Schreglmann, S., \& Öztürk, F. K. (2018). An Evaluation of Gifted Students' Perceptions on Critical Thinking Skills. Journal for the Education of Gifted YoungScientists, 6(1), 1-16.

Sills, S. J., \& Song, C. (2002). Innovations in survey research: An application of webbased surveys. Social Science Computer Review, 20(1), 22-30.

Skinner, E., Saxton, E., Currie, C., \& Shusterman, G. (2017). A motivational account of the undergraduate experience in science: brief measures of students' self-system appraisals, engagement in coursework, and identity as a scientist. International Journal of Science Education, 39(17), 2433-2459.

Steenbergen-Hu, S. \& Olszewski-Kubilius, P. (2017). Factors That Contributed to Gifted Students' Success on STEM Pathways: The Role of Race, Personal Interests, and Aspects of High School Experience. Journal for the Education of the Gifted, 40(2), 99-134.

Stohlmann, M., Moore, T. J., \& Roehrig, G. H. (2012). Considerations for teaching integrated STEM education. Journal of Pre-College Engineering Education Research (JPEER), 2(1), 4.

Tofel-Grehl, C., Feldon, D. F., \& Callahan, C. M. (2018). Impacts of learning standards and testing on gifted learners in STEM schools: A multilevel analytic induction. Roeper Review, 40(2), 130-138.

Trna, J. (2014). IBSE and Gifted Students. Science Education International, 25(1), 19-28.

Tytler, R., Marginson, S., \& Freeman, B. (2014). Widening and deepening the STEM effect. In The Age of STEM (pp. 23-43). Routledge.

Tytler, R., Osborne, J., Williams, G., Tytler, K., \& Cripps Clark, J. (2008). Opening up pathways: Engagement in STEM across the primary-secondary school transition. Retrieved from https://docs.education.gov.au/system/files/doc/other/openpathinscitechmathengi nprimsecschtrans.pdf.

Urban, M. J., Marker, E., \& Falvo, D. A. (2018). An Interdisciplinary Exploration of the Climate Change Issue and Implications for Teaching STEM through Inquiry. In $K$ 12 STEM Education: Breakthroughs in Research and Practice (pp. 1008-1030). IGI Global.

Wang, H. H., Moore, T. J., Roehrig, G. H., \& Park, M. S. (2011). STEM integration: Teacher perceptions and practice. Journal of Pre-College Engineering Education Research (J-PEER), 1(2), 2.

Webb, J., Gore, J., Amend, E., DeVries, A. (2007). A parent's guide to gifted children.Tuscon, AZ: Great Potential Press

Williams, J. (2011). STEM education: Proceed with caution. Design and Technology Education: An International Journal, 16(1), 26-35. 
